\title{
Article
}

\section{Nation, Migration, Identity: Learning from the Cross-Strait Context}

\author{
Momesso, Lara and Lee, Chun-yi \\ Available at http://clok.uclan.ac.uk/26010/ \\ Momesso, Lara ORCID: 0000-0002-4042-9384 and Lee, Chun-yi (2019) Nation, \\ Migration, Identity: Learning from the Cross-Strait Context. International \\ Migration, 57 (4). pp. 218-231. ISSN 0020-7985
}

It is advisable to refer to the publisher's version if you intend to cite from the work. http://dx.doi.org/10.1111/imig.12576

For more information about UCLan's research in this area go to http://www.uclan.ac.uk/researchgroups/ and search for < name of research Group>.

For information about Research generally at UCLan please go to http://www.uclan.ac.uk/research/

All outputs in CLoK are protected by Intellectual Property Rights law, including Copyright law. Copyright, IPR and Moral Rights for the works on this site are retained by the individual authors and/or other copyright owners. Terms and conditions for use of this material are defined in the policies page.

\section{CLoK}

Central Lancashire online Knowledge www.clok.uclan.ac.uk

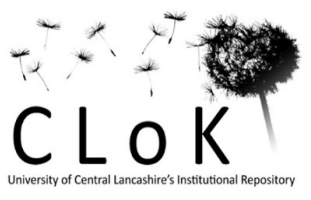




\title{
Nation, Migration, Identity: Learning from the Cross-Strait Context
}

\author{
Lara Momesso, University of Central Lancashire \\ Chun-yi Lee, University of Nottingham
}

\begin{abstract}
It has been argued that globalisation, with its flexible landscapes of production, consumption and mobility, has favoured the emergence of new forms of belonging and identity that are not necessarily built on such principles of the nation state. In this paper, we argue that this process is more likely to happen when movements occur between states that are not in conflictual relations with each other. When the relations between two nations are shaped by conflicts, for instance due to disputes about sovereignty over a territory, nationalism may remain a crucial factor shaping identification and belonging of those who move between the two territories. In this paper, by taking the case of migrants moving between the People's Republic of China and Taiwan, we will shed light on how the issue of "unresolved sovereignty" may eventually lead these actors to reinforce nationalist ideals and identities in their daily narratives and practices, instead of favouring the generation of hybrid identities.
\end{abstract}

\section{Introduction}

In classical literature on identity, the idea that the nation state binds together the lives of people, and therefore their identities, is predominant. By focusing on the nation as the unit of analysis, this literature broadly agrees on the fact that the main form of belonging is provided by the nation-state (Babacan 2010: 11). Yet, these debates have evolved into a new narrative as a consequence of more recent social and economic changes brought about by globalisation, which have deeply undermined states' control over their citizens' actions, movements, possessions, beliefs, and, eventually, the way they frame their identity. This view is taken to an extreme by scholars such as Appadurai (1996), who states that the era based on the logics of the nation is at its end and will be replaced by a postnational era. Within this context, transnational actors, due to their delocalised lives, could easily develop new, hybrid and more flexible identities, instead of or in addition to their traditional national identities (Glick Schiller et al. 1995: 49; Glick Schiller et al. 1992: 1; Grillo et al. 2000: 4). An example is the European Union, which has been celebrated for offering an environment that nurtures supranational identities. The literature argues that, within this context, patterns of identification and belonging have changed considerably as a consequence of the social and economic exchanges occurring with the liberalisation of borders that has taken place in the last few decades. Although several scholars argue that national identity is still prevalent amongst European citizens, there is general agreement on the fact that transnational migration within this region has contributed to the emergence of supra-national identities (Cram 2009; Wodak and Boukala 2015; Tonkiss 2013).

Yet, these reflections are easily applicable to contexts where there is no antagonism between nations and states. Even in the case of the European Union there seems to be a fairly balanced relationship between different states. Indeed, some scholars argue that the fact that all member states surrendered some elements of their sovereignty in exchange for economic, political and symbolic benefits also allowed the emergence of a regional identity (Cram 2009). Yet, what happens when transnational actors move between regions that hold conflicting views with regard to national recognition and sovereignty and that are shaped by unequal relations of power? Can increasing cross-border exchanges, in these contexts, result in flexible and hybrid identities?

By taking the case of cross-border mobility between China and Taiwan, ${ }^{1}$ this paper will explore the

1Considering the specificity of cross-Strait exchanges, it is important to clarify our analytical angle. Although the border between the PRC and Taiwan is not recognised as an international frontier, in this paper we will treat it as such, on the basis that it still involves movements between two social, political and economic spheres that function separately and that are regulated by a bu- 
fixity, rather than fluidity, that may emerge in the way transnational actors frame their identity in a context in which cross-border mobility is coupled with the issue of "unresolved sovereignty", which does not allow the Taiwanese nation to enjoy full recognition as a nation. In this context, identity may eventually be the result of contrasting factors, on the one hand migrants' aspiration to be part of both societies, and, on the other hand, opposing nationalist projects promoted by the two governments and reproduced by the two societies. In this context it is not sufficient to consider transnational actors' aspirations and practices. Isin and Wood (1999) suggest that the concept of identity is a relational concept involving the self and the social spaces that self inhabits. The two scholars argue that identity should be interpreted as a process of self-perception, based on the recognition that certain attributes or properties, which particular individuals regard as important for defining their identity, are constructed on similar features and values as others within a given community. Additionally, identity should also include a broader dimension, namely how a group is perceived by others. This point is important, as when a group moves to a new place, it may question, reformulate and negotiate its identity in light of how it is perceived by the host society.

In contexts in which a community is fighting for recognition as a nation, nationalism may become an important factor shaping how "others" (immigrants) are perceived by the host society, especially if these "others" come from an enemy country. For instance, the fact that Taiwan does not enjoy full recognition as a nation in the People's Republic of China (PRC, China) and internationally, it does not accept Beijing's claims of unification, and it even makes claims of independence and autonomy, becomes a problem when the two peoples enter into contact with each other due to the opposing nationalist projects they hold. Hence, in this paper we will show how an escalation of opportunities for cross-border exchanges between China and Taiwan put cross-Strait migrants into a condition to reflect about their identity, reconsider and reformulate it, not only according to their self-perception and aspirations, but also in response to the nationalist projects of the sending and of the receiving governments and societies. As the narrative of our informants will show, they hardly managed to disentangle the imagination of their selves from the ideal of nationhood, above all the nation where they came from. Hence, with the exception of a few cases, in their narratives and everyday practices, rather than claiming their hybrid identity, they stressed even more their belonging to one or the other nation. In light of these examples, we argue that in a context shaped by an ongoing conflict between two nations and where one nation poses a threat to the survival of the other, identity, eventually, remains deeply entrenched in nationalist logics, to the point that cross-border migrations can became a catalyst for reinforcing and promoting nationalist ideals rather than for generating transnational identities.

This paper builds on the data collected by each scholar during extensive research in the field with Taiwanese businessmen investing in China (Taishangs) and migrants coming from the People's Republic of China (PRC, China) who married Taiwanese citizens (Lupeis). The data on Taiwanese businessmen derive from interviews with Taishangs carried out between 2004 and 2009 in three cities in China: Tianjin, Kunshan and Dongguan. The subsequent fieldwork in relation to Taishangs was conducted between July 2014 and December 2016, in the cities of Beijing, Kunshan and Shanghai. The data on PRC marriage migrants are based on ethnographic work carried out through various long-term visits to Taiwan (between May 2008 and December 2015) and to China (in September 2011 and between January and August 2016). Data collection relied on in-depth interviews with marriage migrants and government officials, as well as participant observation of various civil society organisations advocating for and providing support to marriage migrants in Taiwan. An important feature of both studies is that they build on long-term exchanges with each community of interest, offering a longitudinal perspective of the phenomena as they evolved throughout those years. All the names are pseudonyms.

reaucratic system of control and documentation that, using Friedman's (2015) terms, "mimics" international border crossings. 


\section{Exploring national identity in the cross-Strait context}

Since 1987, with the lifting of the ban on people's movement across the Taiwan Strait and a series of economic agreements made by Beijing and Taipei, there has been a dramatic rise in the volume of economic and social interactions between the two sides of the Strait. According to the Mainland Affairs Council (2016), between 1987 and 2015 the number of Taiwanese visitors to China totalled $87,680,700$. Although movements from China to Taiwan have not enjoyed the same degree of freedom due to restrictions on both sides (Zhu et al. 2008: 421), the Mainland Affairs Council (2016) reported a total of 20,001,200 Chinese visitors to Taiwan in the same period of time. Some migration patterns have also involved permanent relocation to the other side of the Strait and generated new opportunities to engage in transnational practices and arrangements which were not possible before. These changes have also generated new ways of framing identity that were not imaginable decades before.

Empirical literature has extensively explored PRC and Taiwanese citizens' national identities in the context of recent cross-Strait relations. With regard to the PRC, dramatic social and economic changes, engendered by external globalisation and internal social transformation, constituted important challenges to national identity (Jin and Yao 2015; Wang and He 2014). Yet, Beijing managed to preserve a degree of cohesion amongst its nationals on the mainland, for instance by emphasising traditional Chinese culture (Xu 2017). On the other hand, Beijing has not been in control of identity formation on the other side of the Strait. Whereas during the martial law era the Nationalist government emphasised the Chinese cultural roots and identification with a territory that included both China and Taiwan under the control of the Republic of China, as Taiwan began its process of democratisation significant changes occurred with regard to how citizens of Taiwan framed their national identity (Wang 2017; Wilson 2017; Bairner and Hwang 2010; Hao 2010). From an inclusive identity, by which a majority of Taiwanese people saw themselves as Chinese or Chinese and Taiwanese, an exclusive Taiwanese identity started gradually to emerge in the imagination of the Taiwanese population (Wang 2017). Along with rational factors, such as the cost-benefit assessment that could shape the way individuals framed their national membership, a series of other social and political features, such as generation replacement, life experience related to peacetime, economic development and post-materialism, as well as a subjective perception of a diminishing significance of the China factor in Taiwan, contributed to the emergence of an exclusively Taiwanese identity. This new identity posed a clear challenge to the principle of One China, and Beijing did not welcome it with great enthusiasm. The PRC government responded with two opposing approaches to these changes: military and economic threats on the one hand, and favourable economic policies on the other (Wang 2017). Yet, several scholars argue that these actions, rather than strengthening a Chinese political identity in Taiwan, have contributed to forging a Taiwanese consciousness and to turning Taiwan into a "laboratory of identities" instead (Corcuff 2002: xxii).

However, this literature tends to explore identity formation amongst those who lived on one side or the other of the Taiwan Strait. Different reflections can be made if we consider identity formation amongst the communities that formed as a consequence of a recent liberalisation of cross-border exchanges and movements. Extensive cross-border mobility, new technology and democracy created a more liberal environment where individuals could have greater scope of decision on how to move and, eventually, how to frame their identity. On the other hand, the permanence of diplomatic tensions in contemporary cross-Strait relations, with opposing nationalist projects on each side of the Strait, have added new layers of complexity to social and economic phenomena occurring across the Taiwan Strait, identity formation included. The literature on identity of Taiwanese businessmen and students in China is an example. Schubert (2010) argues that Taiwanese investors tend to remain very much attached to their homeland, no matter how long they have worked and lived in China. Although, on different occasions, Taiwanese entrepreneurs may decide to show different "situational identities", such as transnational, cosmopolitan or global, these are mainly strategic choices in order to avoid awkward discussions with Chinese citizens (Schubert 2010). Lan and Wu (2011), fo- 
cusing on Taiwanese students in China, explore how boundaries between themselves and the "others" (Chinese citizens) are constantly constructed in the narratives and practices of Taiwanese students. This point is further developed by Ping (2009), who argues that this persisting Taiwanese identity does not allow a genuine integration of Taiwanese migrants in China. Focusing on individuals' understanding and imagining of their own national identity, this literature overlooks broader factors such as the significance of state policies and social pressure shaping Taiwanese migrants identity in the PRC.

With regard to PRC migrants in Taiwan, the limited scholarship on their identity formation is focused on how structural constraints on their everyday lives, such as the impact of legal restrictions, Taiwanese nationalism, partisan politics and national security, eventually shaped the way they expressed either their Chinese or their Taiwanese identity in public and private spheres (Momesso 2015; Momesso and Lee 2017). Little is said about their self-perception. Clearly, the literature on both sides is still fragmented and incomplete. Above all, this literature is disconnected, as hardly the two groups are explored together. However, by juxtaposing the two cases, it may help to shed light on how both self-perception and the social spaces migrants inhabited can contribute to shaping identity formation for cross-Strait actors.

\section{Self perceptions}

In an expensive apartment in the centre of Xiamen, Robert, a successful Taiwanese businessman who went to China for the first time in 1991 and eventually decided to start a business there in the first half of the 2000s, to the question "what do China and Taiwan represent to you?", answered:

First let me explain something to you. I believe that nation is not a significant thing. Facebook, a population of 5/6 hundred million people, QQ, 6/7 hundred million people. If the government stops working for one week, most likely no one would notice it, but if WeChat does not work, you immediately notice it. So I think nation is a very traditional idea. Apple, Facebook, and this kind of things, they are all transnational things. So boundaries are becoming less and less important. So what is Taiwan? What is mainland? I won't disrespect either ... but for me they are just people. And what we try to do is to live our life. So China is developing, Taiwan is struggling, it is yet to find out its own position. The time for the people of Greater China has come! (interviewed on 25 June 2016, Xiamen, PRC)

Rich and privileged, he could enjoy the best that China, Taiwan and the rest of the world could offer to him. An increasingly rich China offered an expanding market for his business, his children went to an international school in Xiamen, the world offered to the whole family places to visit for holiday and to further expand their business. In a phase of economic expansion in China, they managed to accumulate enough wealth and continue their flexible, fluid, transnational life in Xiamen without being too much bothered by the evolution of cross-Strait relations. Global capitalism, with its flexible landscapes of production, consumption and mobility, has opened up new opportunities to accumulate social and economic capital across borders. The result is the emergence of a privileged class which enjoys the benefits of these changes and has eventually managed to disentangle their identity from the logic of nation. And Robert and his family constitute an example.

The case of Robert is not unique in the literature on cross-Strait actors. It has been argued that Taishangs would use terms such as "transnational", "cosmopolitan", "global", or "hybrid" to describe their identities (Schubert et al. 2016: 33-34). Yet, this seemed rather a strategic approach, to avoid falling into the dichotomy of China/Taiwan relations. The literature argues that Taishangs remain very much attached to their homeland, no matter how long they have worked and lived in the PRC (Schubert 2010). This was confirmed by our interviewees. A majority of our respondents maintained an exclusive approach to identity. For instance, Sarah, a woman from Taichung in her early forties, married to a man from Dongbei province, explained: 
I think I am Taiwanese obviously! You can also say I am (culturally) Chinese, but when I am abroad I will never say I am Chinese, I say I am Taiwanese. No matter I am married to someone from the PRC! I am Taiwanese! I don't want the PRC ID. (interviewed on 8 May 2016, Xiamen)

Sarah had lived in China since 2008. She began her career as a person in charge of the human resources of a company from Hong Kong and she eventually started her own business as a psychology trainer for business and China offered a vast market for this new profession. Sarah rooted her identity in two aspects, an emotional link to Taiwan as well as a pragmatic awareness of the benefits that a Taiwan ID (rather than a Taiwanese national identity) would bring her: "The reason I don't want a mainland ID is that Taiwanese ID is good! Here too, I am paid more as a Taiwanese, even the classes I teach. And it is good to be Taiwanese because local government support me as a Taiwanese." (interviewed on 8 May 2016, Xiamen)

PRC marriage migrants in Taiwan also showed a strong attachment to their homeland national identity, motivated by the fact that they had lived there most of their lives, they had their families there, and they were raised there. As Guocheng, a male spouse from Jiangxi province who arrived in Taiwan in 2002 for marriage, explained:

Often Taiwanese people ask me why mainland spouses, once they have obtained Taiwanese ID, are still faithful to China. They believe that this is cheating Taiwan. What would you say in response to this question? The answer is very easy. There are no spouses thinking in these terms in Taiwan. I tell you, I grew up in China, how can I forget those years there in China? This is not a matter of cheating Taiwan. [...] The issue is related to our life stories. Take me for example. I was born in China, my family is there. I was educated there. In this way I grew up, with certain values and ideas. I came here as a single person, but the rest of the family is in China, you cannot expect that once I arrive here I forget all this. It is not a matter of cheating; it is a matter of life process. (interviewed on 20 October 2014, Taipei)

These narratives, though, are not the whole picture. The whole process of migration and integration into a new society also brought in new complexities to the way our informants understood and framed their identity.

\section{Social positioning and identity}

Social positioning and the way migrants were integrated into society were important factors shaping identity. PRC citizens' position in the receiving society, as mothers/fathers and wives/husbands of Taiwanese citizens, were crucial to generating a specific understanding of their identities. Similarly, to be in China for business and have the rest of the family in Taiwan would shape different interpretations of identity for Taiwanese businessmen.

In the case of PRC marriage migrants in Taiwan, the fact that they became parents of Taiwanese citizens and established a family in Taiwan, pushed them to reconsider their belonging and identity, to the point that some informants argued that they were both Chinese and Taiwanese because they hold families on both sides. Yet, for a group whose family connections and responsibilities concerned both sides, yet whose rights and entitlements were closely related to their membership of one or the other nation, it was difficult to give a coherent answer.

Lupeis have had to face the challenge of ad hoc immigration policies targeting PRC citizens and making the process of acquisition of Taiwanese citizenship difficult, yet necessary. This pushed some respondents to make a distinction between citizenship and identity. As a male marriage migrant who arrived in Kaohsiung in 1994 explained, "I have Taiwanese ID, but I still think that I am 
Chinese. I took Taiwanese ID for reasons related to marriage, for a living. But my family is still in China. And I believe I am Chinese" (interviewed on 24 November 2014, Kaohsiung). Yet, in most cases, the fact that they had to go through the process of acquiring Taiwanese citizenship and renouncing their PRC hukou (household registration system) generated new complexities in the way they understood identity and belonging. All these points are clearly summarised in the words of Meiyu, a woman from Fujian province who had lived in Kinmen, an offshore island of Taiwan, for more than ten years at the time of the interview:

I never thought who I am in a deep way. My place of birth is in China. I have been married in Kinmen for so many years, and I got Kinmen ID, and I have a husband and children here, so I can be regarded as a part of Kinmen. But China still exists, it is still strong the relationship with China. Although my mum was very bad towards me, eventually she is my mum! (interviewed on 4 October 2016, Jincheng township, Kinmen)

In light of this complexity, most Lupeis distinguished national identity, as a subjective, emotional, ideological category, from citizenship, a strategic choice that would allow them access to social, political and civil rights.

Taishangs did not have these concerns: they did not need to apply for PRC ID, as they were entitled to most civil and social rights in China, and even, as Sarah mentioned, had several privileges as Taiwanese citizens in the PRC. Furthermore, their integration in Chinese society was very weak. Taishangs who went to the mainland in the 1980s did not take their families with them. In the 1980s, the economic capacity of Taiwan was stronger than China's: Taiwan was one of the "four dragons" of the East Asian Newly Industrial Economies along with Hong Kong, South Korea and Singapore (Vogel 1991). The standard of living in Taiwan compared to China in the 1980s therefore was much higher. It was a rational choice for Taiwanese businessmen to leave their families behind in Taiwan and to go to China alone with the intention of making better profits. Therefore the superiority of Taishangs arose because Taiwan at that time was a prosperous economy and Taiwanese investors in China, in general, had much more financial capital than their Chinese peers.

Things have changed more recently, and it is possible to note a greater degree of integration of Taiwanese businessmen with local Chinese society. Taiwanese wives started to migrate to China to reunite with their husbands in order to have the family together and to avoid becoming victims of the Chinese mistresses' phenomenon (Hsieh 2015: 91). The arrival of these wives also led to a new phase in the way Taishangs integrated into local society. The housewife of a Taiwanese businessman, who had lived in Suzhou with her husband for fifteen years, explained that:

Taishangs' reputation has not been very good, because of drinking, corruptions and also womanizing. What we (wives) do here is to try to 'renovate' Taishangs image by visiting local orphanages or day homes. We hope to help our husbands' career by improving the image of Taishangs. (interviewed on 5 August 2009)

As well as wives, Taishangs also started to take their children to the mainland for study. Just like Wang (2009: 335), we observed that a good number of Taishang parents have started to send their children to local public schools instead of separate Taishang schools, especially in the last ten years. The establishment of Taishang schools were a milestone of Taishangs' good relationship with local government, starting in Dongguan in 1997 (Lee 2011: 69-70). However, since 2009 many Taishangs have observed the rise of China's economic power and wish their children to pursue their future careers on the mainland instead of in Taiwan, as a Taishang father in Shenzhen explained:

I want my son to study in the local public school because I want him to build his network when he is young. In the future when he starts his business in China, those networks from 
senior or junior high school will turn out very helpful. He won't suffer what I suffered at the beginning, knowing nobody here, building my business from nothing. (interviewed on 17

August 2009)

Despite these new approaches on the side of Taishangs and their families, their critical view on Taiwan, as too traditional, little, and weak, none of our respondents regarded themselves as PRC citizens. The furthest they could go was, as Sarah did, to acknowledge their shared Chinese cultural roots, or the fact that they were Taiwanese in China (Taishang's wife, interviewed in Xiamen, 25 June 2016). Furthermore, in several cases Taishangs' identity in China still remained closely linked to their life in Taiwan. For instance, it was common to see Taishangs, and most of all their Taiwanese wives, relying on Taiwanese products. One of our informants (interviewed in September 2016, Beijing) explained to us that his family still received many parcels from Taiwan containing everyday products, such as soya bean oil, sanitary towels, rice etc. The informant justified it saying not only that he missed Taiwanese products, but, above all, that he did not trust Chinese food. By using Taiwanese daily products, not only did he recreate his hometown in China, but he also furthered the gap between himself as Taiwanese and the receiving society.

From these examples we can see how the way these actors integrated into the receiving society also allowed different imaginations of their identity. Although individuals could come up with different answers and showed a degree of hybridity between Chinese and Taiwanese identity, these two identities hardly would blend with each other harmoniously. In their mind it was always clear that one choice would eventually exclude the other. Clearly, the narratives of most of our informants were shaped by another important feature, national politics: the one-China policy on the side of the PRC and the various perspectives on the Taiwan sovereignty issue on the side of Taiwan.

\section{The influence of national politics}

If several PRC marriage migrants motivated their attachment to their homeland by the fact that they had lived there most of their lives, they had their families there, and they were raised there, some also argued that national politics, above all the principle of One China, played an important role. As one of our informants explained: "this is a matter of education. Since I was young, we learnt that Taiwan is part of China. So I called them [Taiwanese people] Chinese. Because we have nationalism, it's almost a brainwashing" (interviewed on 12 July 2016, Taipei). The main challenge, for people who were raised with the undeniable truth that Taiwan is part of China, was to discover that in Taiwan this principle was constantly questioned. Hence, PRC citizens quickly learnt to avoid mentioning this matter, in public as well as in private spheres, as it would lead to unpleasant consequences. As Guocheng explained, "We don't need to talk about these political issues with our partners. These are political issues, and wife and husband do not need to talk about these problems" (interviewed on 20 October 2014, Taipei).

In the case of Taishangs, identity intersected with the evolving national politics of Taiwan. As a matter of fact, the community of Taishangs can include individuals with different political views. Rigger (2006) argues that identity in Taiwan has been a very complicated issue. It is not just a matter of identifying with China or with Taiwan, as these two entities may have different meanings at different periods of time. Thus a plethora of identities could be identified amongst Taiwanese investors. According to Rigger's research, the first generation of Taiwanese investors in China were born between 1932 and 1956. Rigger categorised them as the second generation of Taiwanese, a group that "produced an ideology that celebrates Taiwan identity [...] (and rejects) Chinese identity" (Rigger 2006: 42). Yet, the "Chinese identity" stressed by Rigger refers to the PRC and not to the Republic of China (ROC). More recently, the ideal of Taiwanese identity became detached from the ROC/PRC dichotomy, and instead emphasised Taiwanese self-determination. In some cases, younger Taishangs reflected these new trends in their narratives. For instance, a young Taiwanese 
investor openly confirmed that he was a supporter of the Democratic Progressive Party, a party with a clear pro-independence stance, during the years of Chen Shui-bian's presidency (interviewed on 29 August 2008, Tianjing). Yet, despite these different perspectives, capitalism and economic interests are revealed to be the main driving force behind Taiwanese businessmen's political identities.

Chuang (2011) argues that during the 1996 missile crisis, Taishangs travelled back and forth across the Strait to persuade the two governments to separate politics and economics. Lee (2013) also argues that Taiwanese businessmen focussed more on protecting their economic interests as a core principle; whether the ruling party was blue (KMT), green (DPP) or red (CCP) was not of much concern to them. Echoing these arguments, one of our informants explained that manifesting his political ideals in China was not in his interests, to the point that he even changed his political orientations over the years in order not to threaten the development of his business (interviewed on $29 \mathrm{Au}-$ gust 2008, Tianjing). Taishangs disenchantment with Taiwanese politics was also coupled by a lack of systematic support on the side of the Taiwanese government. It is true that the Taiwanese government had tried several different pathways for Taiwanese investment abroad, not only in China but also increasingly in Southeast Asian countries. The 1996 Go South Policy and, more recently, the New Southbound Policy are two examples. Nevertheless, Taiwan's foreign direct investment strategy, in comparison to other Asian countries such as Korea and Japan, has been much less centralised. The Ministry of Economic Affairs adopted a non-intervention policy in relation to Taiwan's foreign investment (Cheng et al. 1997: 98). Although the Taiwanese government regularly met with Taishangs three times a year (Chinese New Year, Dragonboat Festival and Moon Festival), Taiwanese businessmen did not consider this strategy systematic and efficient. This is also proved by an informant who had invested in Vietnam for more than twenty years. As he argued, there has been not much difference for his business since the government started to promote the New Southbound Policy (interviewed on March 20, 2018, Ho Chih Minh city). Thus, most small and medium-sized Taiwanese businesses have received little support from the government of Taipei. In addition, the fact that most Taishangs made profits in the PRC and did not transfer the profits back to Taiwan meant that Taishangs did not bring significant economic benefits to Taiwan. Consequently, the Taiwanese government has always maintained a weak role in supporting Taiwanese overseas investments, although Taishangs still had an important political role as voters in Taiwan (Schubert 2016: 218-219). This has made the relationship between Taishangs and their government rather loose, leading, often, to Taishangs' disappointment about their government's lack of support for their investments in the PRC.

On the contrary, Taishangs have enjoyed privileged treatment in China. For instance, Beijing encouraged local governments to be flexible towards Taiwanese investors in order to bypass the restrictions imposed by the World Trade Organisation (WTO) requiring equal treatment for all WTO members. Complying with WTO regulations would require Beijing not to grant special privileges to any specific investors, including Taiwanese investors (Economic Daily 1996). Nevertheless, both Chinese local and central governments continued to grant economic favours to Taiwanese businesses, for instance, in the case of Want Want, a big Taiwanese business that has invested in the PRC since 1991 (Lin and Lee 2017: 37-47). Even after China entered the WTO, Want Want still gained preferential access to other businesses, including insurance, hospitals and restaurants. Want Want became a conglomerate at the provincial level. Other Taiwanese investors received similar treatment in the PRC. This point was confirmed by several interviewees, examples being better land rental and longer tax breaks, also local governments' guarantee of stability of electricity and workers' supplies (interviewed in: Tianjin, 14 and 18 November 2004; Kunshan, 30 November and 9 December 2004; Dongguan, 20 and 23 December 2005). The extra favours that the Beijing government provided for Taishangs were intended to buy their hearts and minds with the expectation that they would influence Taiwan's politics in favour of reunification (Lee 2011). Yet, their narratives seem to emphasise a pragmatic approach to China in both private and public spheres, despite the various strategies developed by Beijing to warmly welcome Taishangs in its territory. 
As these examples showed, although our informants questioned their original identity and came out with different solutions to the challenges and opportunities created by their transnational lives, these narratives were rarely articulated outside of the dichotomy of Chinese or Taiwanese identity. And, in the context of cross-Strait relations, the ongoing conflict over the issue of Taiwan's sovereignty required cross-Strait migrants to prioritise either one identity or the other each time, limiting their freedom to imagine and develop hybrid identities. This condition was even more apparent in the way these migrants framed their identity in public spaces.

\section{Performing identity}

The complex answers given by our informants in private spaces did not always correspond to how they expressed identity in public spaces. In the context of an authoritarian government allowing only one official truth with regard to the "Taiwan issue", Taiwanese citizens in the PRC opted to censor themselves in order to avoid falling into awkward situations or conversations or to avoid compromising their economic interests. There was no reason for Taishangs to openly demonstrate their already vague political identity, with the risk of jeopardising their existing preferential benefits (for instance tax waivers or cheaper land rental) from the Chinese government. Thus, at public events, especially in the presence of local Chinese officials, they opted to avoid expressing their identity, and just talk about business. In this case, the political context of China, with an authoritarian government, did not allow choices on how to manifest identity if this was different from the official narrative.

On the other side of the Strait, PRC marriage migrants did not experience greater freedom, despite the presence of a democratic society. Especially in the first half of the 2000 s, when a pro-independence government ruled the country and Lupeis were construed as enemies of the Taiwanese nation, they found it difficult to freely manifest their Chinese identity. Not only PRC marriage migrants had to face the challenge of unfair immigration policies, they also had to face a discriminatory narrative produced by the media and embraced by the public in Taiwan. This narrative stressed differences between Lupeis and the rest of the Taiwanese nation and emphasised the political threat that PRC marriage migrants could entail for the Taiwanese nation (Hsia 2007). Seeing its national sovereignty as threatened by the arrival of migrants from the PRC, the Taiwanese government made every effort to exclude these migrants from its nation-building project. As a consequence, PRC marriage migrants not only felt excluded, but also did not dare to manifest pride for their Chinese identity in public spaces or in front of other Taiwanese citizens. Candy, a woman from Jilin province, who had lived in Kaohsiung for more than ten years at the time of the interview, explained:

I could not talk freely and say that Taiwan is a province of China, especially here in the South. So many Taiwanese curse us and say that we are "the running dogs of China". [...] I do understand their perspective when they say that they are not part of China. They think that China and Taiwan are two separate places. So they say "our nation", but often they tell us that we are all compatriots. So sometimes they think that we are two separate entities, sometimes they think that we come from the same roots. (interviewed on 4 December 2014, Kaohsiung)

Yet, differently from Taishangs, Lupeis opted to emphasise their connection with and contributions to the Taiwanese nation, by showing their love and loyalty to Taiwan in public spaces. As they entered Taiwan for family reasons, they used their identities as mothers, wives and daughters-in-law of Taiwanese citizens to legitimise their inclusion in the Taiwanese nation (Chao 2006; King 2011). The civil rights movement that emerged between the end of the 1990s and early 2000s, seeking better legal treatment of PRC marriage migrants, built on a similar narrative stressing their love for Taiwan as a way to promote inclusion and integration of these migrants (Momesso and Cheng 2017). 
Things have changed in the last decade though, with Beijing turning its attention towards groups residing in Taiwan. In line with a people-oriented approach aimed at reaching out to small and medium-sized enterprises, the middle and lower classes, and the common people in central and southern Taiwan, as well as young people (Romberg 2014: 13), Beijing eventually decided to formalise previously unofficial links with PRC marriage migrants' civic organisations in Taiwan. PRC marriage migrants' civic organisations were invited to official activities in China, such as the Cross-Strait Marriage Family Forum, a yearly event in which government officials, academics, professionals in the field and members of cross-Strait families discuss the theme of marriage migration and family formation across the Taiwan Strait. Furthermore, the children of cross-Strait families residing in Taiwan have also been invited to China with the purpose of establishing a connection between them and their Chinese roots (Momesso 2017: 913). Also, the government has started to integrate crossStrait marriage migration into a broader official narrative on cross-Strait harmony and peace (Momesso 2017: 912) and media reports about cross-Strait marriage migration in the PRC has become more positive in tone (Wang 2015: 20).

Interestingly, as Beijing changed its approach towards PRC marriage migrants and as China turned into a global economic power over the last decade, Lupeis started to develop new narratives with regard to their identity. Especially in the period 2008-2016, due to the improved cross-Strait relations and favourable political opportunities in Taiwan (with a pro-China government), Lupeis could stress, as never before, their dual identities, as Taiwanese and Chinese citizens, even in public spaces. Picking up on the positive public narrative initiated by Beijing towards Lupeis in China, and taking advantage of a friendlier political atmosphere towards China in Taiwan, PRC marriage migrants began to emphasise their dual identity, as Chinese and Taiwanese, and as bridges who brought together the two societies across the Taiwan Strait. This is the first time that a group of cross-Strait actors has clearly manifested their identity in these terms. This did not last very long though, as, with more recent changes in Taiwan's domestic politics (the election of a pro-independence government in 2016), the consequent worsening of cross-Strait relations and the emergence of Taiwanese nationalism, Lupeis had to silence again their Chinese side and, instead, stress their Taiwanese identity and belonging.

\section{Conclusion}

By focusing on the cross-Strait context, this paper asks whether and to what extent increased crossborder exchanges have impacted on the way transnational migrants imagine and understand their identities. Several scholars exploring recent cross-Strait integration suggest that economic integration will lead to political unification and, eventually, to erasing the antagonisms created by the different nationalist projects between Taiwan and China. Our findings, based on the narratives of cross-Strait migrants, show that nationalist sentiments never disappeared; rather, they changed in reaction to the evolution of cross-Strait relations and Taiwanese domestic politics and to the dissimilar space offered to migrants to express their identities at different time in public spaces.

As the narratives of our informants showed, individuals may have different interpretations with regard to how to frame their identity, and this could be shaped by their life experiences and their practices and movements across borders. Gender, education and social class, as well as the way migrants are integrated into the receiving society, may shape different concepts of identity as well as different solutions to the challenges posed by cross-border mobility.

However, in this paper we have showed how people's flexibility eventually had to come to terms with the restrictions imposed by the politicised environment they inhabited. The unresolved issue of Taiwan's sovereignty has generated, throughout these years, constant changes in the way these migrants could manifest their identities in public spaces. Although migrants strategised the different nationalist projects in various ways, it is clear how these broader factors deeply shaped the narra- 
tives of our respondents. In this context, identity remained closely entangled with the nationalist logics of the two governments. Hence, we argue that, in the context of antagonistic relations between nations and states, increasing cross-border exchanges and mobility do not necessarily lead to the emergence of hybrid and fluid identities. Without a condition of a fairly balanced relationship between states it is impossible to see certain changes in the way transnational migrants understand and frame their identities.

Finally, this paper shows that, when a community of people suffers lack of recognition as a nation and is in a subaltern position against a rival dominant power, national identity may remain a significant category of identification for those who move between the two societies. As governments may seek to strategise those who move across borders to pursue their nationalist objectives, hybrid, supra-national and post-national identities are less likely to emerge, and, instead, transnational migration could be the catalyst for reinforcing and promoting nationalist ideals and identities, rather than contributing to their weakening.

\section{References}

Appadurai, A.

1996 Modernity at Large: Cultural Dimensions of Globalization, Minneapolis, University of Minnesota Press.

Babacan, $\mathrm{H}$.

2010 "Immigration, nation state and belonging", in: Babacan, A. and Singh, S. (eds.) Migration, Belonging and the Nation State, Newcastle upon Tyne, Cambridge Scholars Publishing, pp. 7-30.

Bairner, A. and Hwang, D-j.

2010 "Representing Taiwan: international sport, ethnicity and national identity in the Republic of China", International Review for the Sociology of Sport, 46 (3): 231-248.

Chao, A.

2006 "Politics of sentiment and alternative social justice: how mainland spouses have engaged in

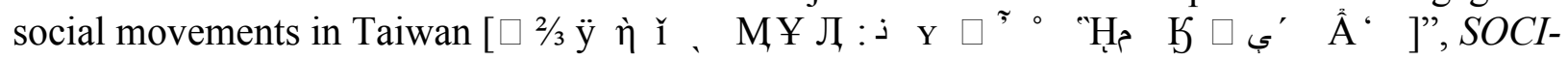

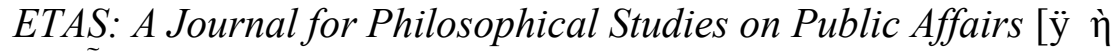

1 $\quad \uparrow_{\mathrm{z}}$ ], 16 (March): 87-152 (in Chinese).

Cheng, T-j., Haggard, S., and Kang, D.

1997 "Institutions and growth in South Korea and Taiwan: the bureaucracy", The Journal of Development Studies, 34 (6): 87-111.

Chuang, Y-c.

2011 "Taiwanese identity in a global/local context: the use and abuse of national consciousness in Taiwan", in Aspalter, C. (ed.) Understanding Modern Taiwan: Essays in Economics, Politics and Social Policy, Aldershot, Ashgate.

Corcuff, S.

2002 "Introduction: Taiwan, a laboratory of identities", in: Corcuff, S. (ed.) Memories of the Future: National Identity Issues and the Search for a New Taiwan, Armonk, New York, M.E. Sharpe, pp. xi-xxiv.

Cram, L.

2009 "Identity and European integration: diversity and a source of integration", Nations and Nationalism, 15 (1): 109-128. 


\section{Economic Daily}

1996 "Special tax bonus decreased gradually: the Chinese government emphasized serving Taiwanese businessmen rather than offering them preferential conditions", Economic Daily, 16 May 1996.

Friedman, S.

2015 Exceptional States: Chinese Immigrants and Taiwan Sovereignty, Oakland (CA), University of California Press.

Glick Schiller, N., Basch, N., and Blan-Szanton, C.

1992 "Transnationalism: A new analytic framework for understanding migration", in: Glick Schiller, N., Basch, N., and Blan-Szanton, C. (eds.) Towards a Transnational Perspective on Migration: Race, Class, Ethnicity, and Nationalism Reconsidered, New York, The New York Academy of Science, pp. 1-24.

Glick Schiller, N., Basch, L., and Blan-Szanton, C.

1995 "From immigrant to transmigrant: theorizing transnational migration", Anthropological Quarterly 68 (1): 48-63.

Grillo, R., Riccio, B., and Salih, R.

2000 Here or There? Contrasting Experiences of Transnationalism: Moroccans and Senegalese in Italy, Falmer, University of Sussex.

Hao, Z-d. 2010 Whither Taiwan and Mainland China: National Identity, the State, and Intellectuals, Hong Kong, Hong Kong University Press.

Hsia, H-c.

2007 "Imaged and imagined threat to the nation: the media construction of the 'foreign brides' as social problems in Taiwan", Inter-Asia Cultural Studies, 8 (1): 55-85.

Hsieh, H-c.

2015 'Representations of familial intimacy across the Taiwan Strait: The reinvention of homeness among Taiwanese wives in documentaries', China Information, 29(1): 89-106.

Isin, E.F. and Wood, P.K.

1999 Citizenship and Identity, London, Sage.

Jin, T-j. and Yao, $\mathrm{H}$.

2015 "National identity in the context of globalisation: a structural perspective", Social Sciences in China, 36 (2): 110-126.

King, W.

2011 "Taiwanese nationalism and cross-strait marriage. Governing and incorporating mainland spouses", in: Schubert, G., and Damm, J. (eds.) Taiwanese Identity in the 21st Century: Domestic, Regional and Global Perspectives, Abingdon, Routledge, pp. 176-193.

Lan, P-c. and $\mathrm{Wu}, \mathrm{Y}-\mathrm{f}$.

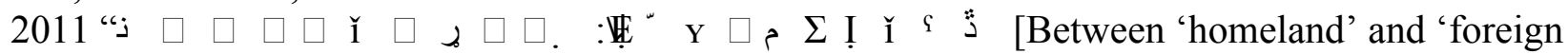
country': liminal identity and boundary work of Taiwanese students in China]", Taiwanese Sociology, 22: 1-57. 
Lee, C-y.

2011 Taiwanese Businessmen or Chinese Security Asset, London, Routledge.

Lee, C-y.

2013 "From being privileged to being localised? Taiwanese businessmen in China", in: Lin, P.,

Chiu, K-f., and Fell, D. (eds.) Migration to and from Taiwan Strait, London, Routledge.

Lee, T-h.

1999 "Understanding Taiwan: bridging the perception gap", Foreign Affairs, 78 (6): 9-14.

Lin, L-y. and Lee C-y.

2017 "When business met politics", China Perspective, 2: 37-47.

Mainland Affairs Council

2016 Preliminary statistics of cross-Strait economic relations, available at:

www.mac.gov.tw/public/Data/6216141702.pdf (accessed 20 September 2016).

Momesso, L.

2015 "Between official and concealed: cross-Strait marriage migrants' strategies of resistance", in: Lipinsky, A. (ed.) Immigration Societies: Taiwan and Beyond. Vienna Taiwan Studies Series Vol. 1, Berlin, LIT, pp. 171-193.

Momesso, L.

2017 "Marriage migration and state interests: reflections from the experiences of marriage migrants from the People's Republic of China in Taiwan”, Asiatische Studien, 70 (3): 903-920.

Momesso, L., and Cheng, I.

2017 "A team player pursuing its own dreams: rights-claim campaign of Chinese migrant spouses in the migrant movement before and after 2008", in: Fell, D. (ed.) Taiwan's Social Movements under Ma Ying-jeou: From the Wild Strawberries to the Sunflowers, Abingdon, Routledge, pp. 219235.

Momesso, L., and Lee, C-y.

2017 "Transnational mobility, strong states and contested sovereignty: learning from the ChinaTaiwan context", Asian and Pacific Migration Journal, 26 (4): 459-479.

Ping, L.

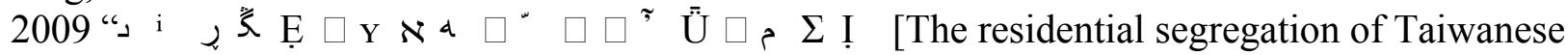
people in China]," Taiwan Political Science Review, 13 (2): 57-111.

Rigger, S.

2006 Taiwan's Rising Rationalism: Generations, politics, and "Taiwanese Nationalism”, Policy Studies, Washington DC, East-West Centre.

Romberg, A. D.

2014 "Cross-Strait relations: portrayals of consistency calm on the surface, paddling like hell underneath”, China Leadership Monitor, Fall 2014 (45): 1-26.

Schubert, G.

2010 "The political thinking of the mainland taishang: some preliminary observations from the field", Journal of Current Chinese Affairs, 39 (1): 73-110. 
Schubert, G.

2016 “Taiwan's Mainland entrepreneurs (Taishangs)", in: Schubert, G. (ed.) Routledge Handbook of Contemporary Taiwan, Oxford and New York, Routledge.

Schubert, G., Lin, R-h. and Tseng, Y-c.

2016 “Taishang studies. A Rising or declining research field?", China Perspectives, 1: 29-36.

Tonkiss, $\mathrm{K}$.

2013 "Post-national citizenship without post-national identity? A case study of UK immigration policy and intra-EU migration", Journal of Global Ethics, 9 (1): 35-48.

Vogel, E.F.

1991 The Four Little Dragons: The Spread of Industrialisation in East Asia, Harvard University Press, Cambridge.

Wang, H-1.

2009 "How are Taiwanese Shanghaied?", Position, 17(2): 321-346.

Wang, A. H-e.

2017 "The waning effect of China's carrot and stick policies on Taiwanese people", Asian Survey, 57 (3): 475-503.

Wang, $\mathrm{P}$.

2015 "Media presentations of cross-Strait marriage in contemporary China", China Media Research, 11 (2): 17-28.

Wang, Z-j. and He, H-1.

2014 "Special issue: national identity in the course of globalisation", Social Sciences in China, 35 (2): 139-154.

Wilson, K.

2017 "Party politics and national identity in Taiwan's South China Sea claims. Don't Rock the Boat", Asian Survey, 57 (2): 271-296.

Wodak, R. and Boukala, S.

2015 "European identities and the revival of nationalism in the European Union. A discourse historical approach", Journal of Language and Politics, 14 (1): 87-109.

$\mathrm{Xu}, \mathrm{S}-\mathrm{q}$.

2017 "Cultivating national identity with traditional culture: China's experiences and paradoxes", Discourse: Studies in the Cultural Politics of Education: 1-14. doi:

10.1080/01596306.2017.1302410.

Zhu, Y., Lin, L-y., Qi, X-h., and Xia, J-1.

2008 "China", Asian and Pacific Migration Journal, 17 (3-4): 419-428. 